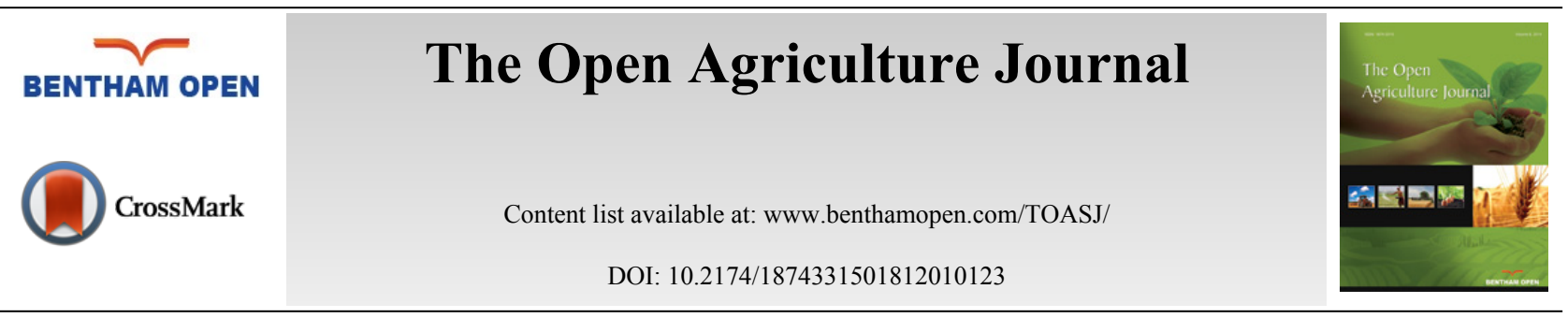

RESEARCH ARTICLE

\title{
Response of Seeds Quality of Sunflower to Inoculation with Single and Mixed Species of Indigenous Arbuscular Mycorrhizal Fungi
}

\author{
Mazen Ibrahim* \\ Agriculture Department, Atomic Energy Commission of Syria (AECS), Damascus, Syria
}

Received: January 01, 2018

Revised: February 18, 2018

Accepted: June 10, 2018

\begin{abstract}
:
Background:

The sunflower seeds which are popular in Syria and Mediterranean countries as a roasted or salted snack, supply a large number of nutritious components including protein and minerals. A pot experiment was conducted to determine the impact of indigenous Arbuscular Mycorrhizal Fungi (AMF) on phosphorus (P), nitrogen (N), and protein content in seeds of confection-type hybrid sunflower (Helianthus annuus L.). The indigenous AMF including Glomus intraradices, Glomus mosseae, and Glomus viscosum, were isolated from an agricultural field in Syria. The most abundant species ( $G$. viscosum) was multiplied in monospecific culture.
\end{abstract}

\section{Method:}

Sunflower plants were inoculated with the mixture of three AMF species or with G. viscosum. The plants were harvested at full physiological maturity stage. Total $\mathrm{N}$ was determined using the Kjeldhal method and the detection of phosphorus was based on the colorimetric method. The rate of AMF-root colonization was determined microscopically by the gridline intersect method.

\section{Result:}

Seeds $\mathrm{N}$ and $\mathrm{P}$ content were enhanced by the inoculation of sunflower with single and mixture of AMF compared with non-AM plants. Higher content of $\mathrm{N}$ and $\mathrm{P}$ was observed in AMF mixture inoculation compared to individual inoculation with G. viscosum. The maximum protein concentration was found in the treatment of mixture AMF followed by individual inoculation with $G$. viscosum. The results indicated that mixed species of AMF were more species, and could be considered as a good inoculum for improving the seeds quality of sunflower grown under sustainable agriculture conditions.

Keywords: AMF, Sunflower, Phosphorus, Nitrogen, Protein, G. Viscosum.

\section{INTRODUCTION}

The sunflower seeds are popular in Syria and some Mediterranean countries as freshly roasted or salted snack. Yields of non-oil or confection-type sunflowers are closely tied to the quality of the seeds [1]. The sunflower seed contains a large number of nutritious components including minerals and protein [2]. On the other hand, seed proteins provide the sulfur $(\mathrm{S})$ and nitrogen $(\mathrm{N})$ needed for seedling development after germination [3]. Seeds productivity and quality are greatly affected by genotype and environmental factors. According to Nel and Loubser [4], seeds quality of sunflower is influenced by environmental more than by genetic effects. In conventional agriculture, improving seeds yield and quality can be conducted through the addition of chemical fertilizers [5] but the production of 'nutrient-rich high-quality seeds' in sustainable comportment demands the use of natural microflora of the soil rhizosphere [6].

Arbuscular Mycorrhizal Fungi (AMF) are an important component of the useful microbial community in the soil. AMF play an essential role in the nutrients uptake of the majority of plants, including many important crop species [7].

\footnotetext{
* Address correspondence to this author at the Agriculture Department, Atomic Energy Commission of Syria (AECS), 17th Nissan St., Kafersouseh, Damascus, Syria; Tel: 00963112132580; E-mail: ascientific6@aec.org.sy
} 
The extraradical mycelium spreads around the root and enhances the root surface area by which the AMF absorb and transport nutrients to the host plant [8]. Positive responses of sunflower to colonization by AMF were reported for growth and seed yield [9 - 11]. AMF can provide the dominant route for phosphorus supply to the plant [12] and strongly impact the distribution of nitrogen in seeds, increasing protein content [13]. The native species of AMF can function better in agricultural soils from which they are isolated [14]. However, there is a high intraspecific diversity between different isolates of one AMF species [15]. The diversity of AMF species in the roots was found to be correlated positively with phosphorus and nitrogen concentrations in plant shoot [16]. AMF species can generate different amounts of extraradical mycelium and can have different efficiencies in phosphate uptake [17 - 19], consequently, AMF species could influence plant growth differently [20]. The growth response can be highly positive when plant roots are colonized by AMF species that are complementary in nutrients uptake from soil pools. Thus, the AMF mixture may be more beneficial for the plant growth than any of the species separately [21, 22]. We hypothesized that indigenous species of AMF influence differentially the quality of seeds of sunflower grown in soil from which $\mathrm{AMF}$ is isolated. To test the hypothesis, sunflower plants were separately inoculated with single, or mixture of AMF species under sustainable agriculture conditions, to reveal the impact of the two types of inocula on the N, P and protein contents in seeds.

\section{MATERIALS AND METHODS}

\subsection{Experimental Site}

This experiment was conducted in plastic pots during the summer season (May to September 2015) at AECS Research Station, located within an arid region southeast of Damascus, Syria $\left(33^{\circ} 21^{\prime}\right.$ N, $36^{\circ} 28^{\prime}$ E) at $617 \mathrm{~m}$ above sea level. Sandy clay loam soil with pH 8.5 , organic matter $1.8 \%$, was air dried, sieved to pass a $3 \mathrm{~mm}$ screen, and pasteurized at $5 \mathrm{kGy}$ of Gamma Ray (GR) with 60Co source using a gamma irradiator (ROBO, Russia).

\subsection{AMF Inoculum Preparation}

AMF propagules were obtained from the soil previously isolated [23] from an agricultural field in which cotton and sunflower were grown. For propagating AMF, pot-cultures were established by mixing original soil samples with sterilized sand $(1: 1 \mathrm{v} / \mathrm{v})$ as a substrate for growth of onion (Allium cepa L.) as the trap plant. Pot-cultures were conducted during two successive cycles of 4 months. Plants were fertilized once a week with $20 \mathrm{ml}$ Long Ashton nutrient solution [24] containing reduced P concentration. AMF isolate included Glomus intraradices (Schenck \& Smith), Glomus viscosum (Nicolson), and Glomus mosseae (Nicol. \& Gerd., Gerd. \& Trappe). G. viscosum as the most abundant specie (based on the number of viable spores in the trap substrate) was multiplied in monospecific culture. This culture was produced in pots containing a 1:1 autoclaved soil:sand mix (vol/vol) by inoculation onion roots with the spores of G. viscosum. The whole pot's content was air-dried and the roots were cut into 1-cm pieces and thoroughly mixed with the soil:sand substrate. The inoculum of the two AMF types consisted of fragments of onion root, mycelium and spores mixed with the substrate. The inoculum contained 580 propagules (spores, hyphae and colonized roots) per $100 \mathrm{~g}$ as determined using the Most Probable Number (MPN) assay [25].

\subsection{Planting Procedures and Treatments}

Four seeds of confection-type hybrid sunflower were sown in each pot $(40 \mathrm{x} 45 \mathrm{~cm}$ ) containing $35 \mathrm{~kg}$ soil. Half of the pots received the AM inoculum (100 g per pot) by layering at $10 \mathrm{~cm}$ depth of the pots at the time of sowing. Two types of AMF inocula were used in this experiment: mixed species of AMF that included G. intraradices, G. viscosum, and G. mosseae, and the single specie (G. viscosum). Non-AM pots received the same amount of sterilized AMF inoculums. Seedlings were thinned to one per pot with keeping the roots of discarded plants in the soil to avoid removing the AMF inoculum. The experiment involved three treatments: control (no AMF inoculation), inoculation with AMF mixture, and inoculation with $G$. viscosum. The pots were arranged in a randomized complete block design with four replicates. The plants were grown under natural conditions with an average daylength $14 \mathrm{~h}, \mathrm{max} / \mathrm{min}$ temperature $36^{\circ} / 17^{\circ} \mathrm{C}$, and average relative humidity $40 \%$. No chemical fertilizers were added, and adequate soil moisture was maintained during the experiment.

\subsection{Plant Sampling and Analysis}

The plants were harvested at full physiological maturity stage. The seeds samples were ground and used for measuring nitrogen and phosphorus content. Total nitrogen content was determined using the Kjeldhal method [26]. 
The protein content was estimated by multiplying total $\mathrm{N}$ by nitrogen-to-protein conversion factor 6.25 . The detection of phosphorus was based on the colorimetric method [26] using spectrophotometer (Thermo Spectronic, UK). The content of each nutrient (mg per plant) was obtained by multiplying nutrient concentration by seeds dry weight.

\subsection{Determination of AMF Colonization}

Roots samples were rinsed in tap water and cut into $1 \mathrm{~cm}$ fragments. The root segments, totally mixed, were cleared in $10 \%(\mathrm{w} / \mathrm{v}) \mathrm{KOH}$ by heating at $90^{\circ} \mathrm{C}$ for 30 to 60 minutes, depending on the degree of lignification of the roots. It was then washed and stained with acid fuchsin in lactoglycerol. The rate of AMF-root colonization was determined under a binocular microscope by the gridline intersect method [27].

\subsection{Statistical Analysis}

The analysis of variance was done by the SAS program [28]. Means between the studied parameters were compared using Fisher's Least Significant Difference (LSD) test at a confidence level of 5\%.

\section{RESULTS AND DISCUSSION}

No AM colonization was noted in non-inoculated plants. AMF structures, i.e. arbuscules, vesicles and hyphae were observed in the root of inoculated plants at harvest (Fig. 1). However, no significant difference was found for the rate of AMF-root colonization of sunflower plants inoculated with single and mixed species of AMF (Table 1).

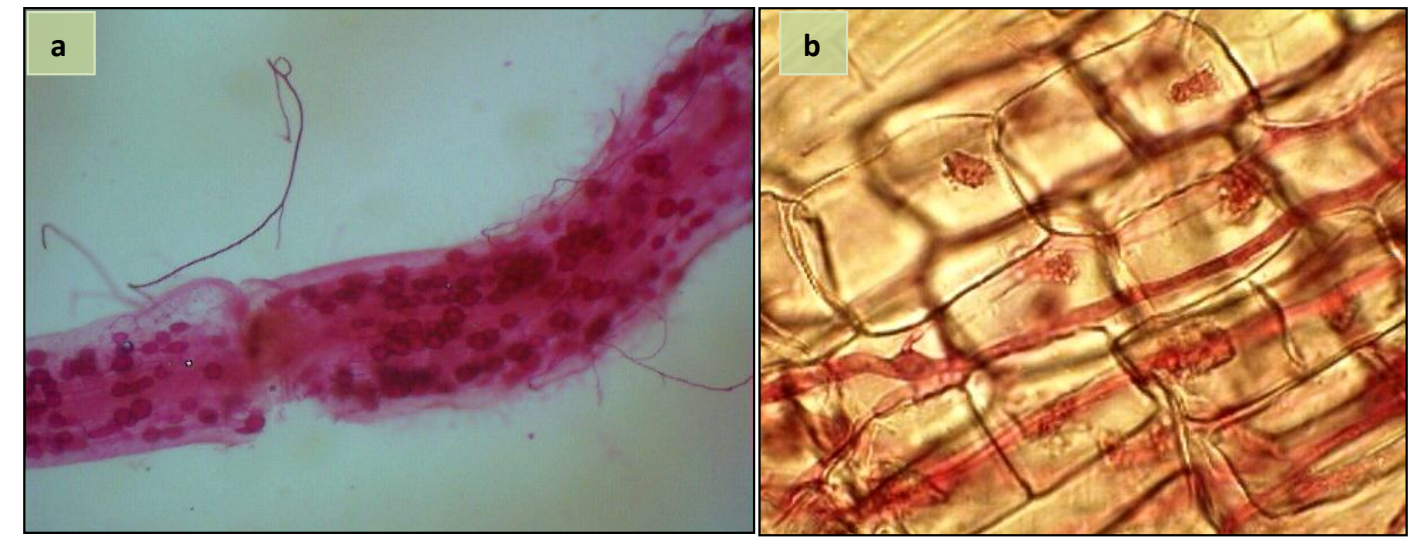

Fig. (1). AMF structures: vesicles and hyphae (a), and arbuscules (b) in sunflower root samples.

Table 1. AM colonization, plant height, plant weight, seeds weight, and seed protein concentration in sunflower inoculated with single specie (Glomus viscosum) and mixture of AMF species.

\begin{tabular}{|c|c|c|c|c|c|}
\hline Treatment & AM Colonization (\%) & $\begin{array}{c}\text { Plant Height } \\
(\mathbf{m})\end{array}$ & $\begin{array}{c}\text { Plant Dry Weight } \\
(\mathbf{g})\end{array}$ & $\begin{array}{c}\text { Seeds Weight } \\
\left(\mathbf{g}_{\text {plant }} \mathbf{-}^{-1}\right.\end{array}$ & $\begin{array}{c}\text { Protein } \\
(\mathbf{\%})\end{array}$ \\
\hline Control & 0 & $1.35 \pm 0.05$ & $56.3 \pm 5.9$ & $20.7 \pm 1.35 \mathrm{c}$ & $14.95 \pm 0.19 \mathrm{c}$ \\
\hline Single AMF & $24.9 \pm 1.7 \mathrm{a}$ & $1.56 \pm 0.04$ & $81.9 \pm 4.3$ & $33.4 \pm 0.69 \mathrm{~b}$ & $17.90 \pm 0.13 \mathrm{~b}$ \\
\hline mixed AMF & $27.6 \pm 2.0 \mathrm{a}$ & $1.71 \pm 0.06$ & $96.8 \pm 8.5$ & $39.5 \pm 3.64 \mathrm{a}$ & $18.44 \pm 0.18 \mathrm{a}$ \\
\hline$L S D$ & 3.03 & 0.99 & 12.9 & 4.5 & 0.34 \\
\hline
\end{tabular}

Values (mean \pm SD) in the same column followed by different letters are significantly different at $\mathrm{P}<0.05$ lead by Fisher's Least Significant Difference (LSD) test .

The P content was significantly greater in the seed of AM plants than the control (Fig. 2). This result was supported by Heidari and Karami [29] who showed that mycorrhiza treatment had a significant effect on P content in sunflower seeds. The inoculation with $A M F$ enhanced P concentration in wheat grain [30] and in grain and vegetative tissue of barley [31]. In this study, the inoculation with single and mixture AMF significantly increased seed P concentration by 47 and $79.7 \%$ over the control (Fig. 4). This increase in seed P by AMF could be explained by the improvement of $P$ uptake per unit of root length due to the enhancement of root surface area and providing an extra route for P uptake as mycorrhizal pathway [12]. The inoculation of mixed species induced higher P content in sunflower seeds compared to the individual inoculation of G. viscosum (Fig. 2). The increase in P content by AMF mixture was supported by the finding of earlier studies in cotton [32] and tomato [33]. Leek plants colonized by a mixture of G. claroideum and G. 
intraradices acquired more $\mathrm{P}$ than plants colonized with either of the two AMF separately [34]. Johnson et al. [16] reported that the $\mathrm{P}$ and $\mathrm{N}$ concentrations in the shoot were correlated positively with the diversity of AMF species in the roots. The difference in $\mathrm{P}$ content between the two inocula can be attributed to the different ability of AMF species to acquire resources below ground. AMF species can produce different amounts of extraradical mycelium and can have different efficiencies in phosphate uptake [17 - 19]. Moreover, the mycelium of AMF species uptake P from different distances from the roots $[19,35]$.

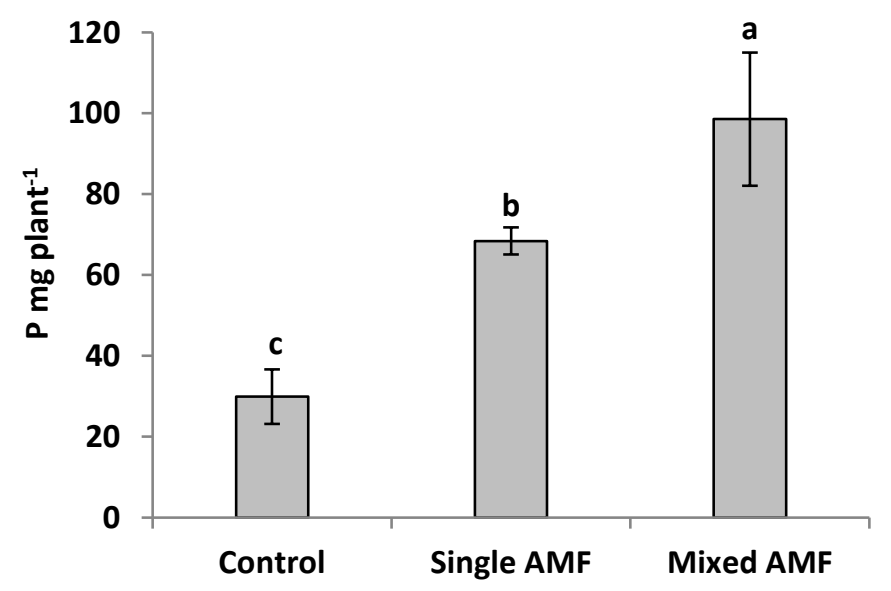

Fig. (2). Effect of the inoculation with single AMF (Glomus viscosum) and mixture of AMF on P content in sunflower seeds. Vertical bars represent means \pm SD $(n=4)$. Different letters on square bars indicate significant difference at $\mathrm{P}<0.05$ lead by Fisher's Least Significant Difference (LSD) test. LSD $=20.8$.

In this study, inoculation with indigenous AMF significantly increased the $\mathrm{N}$ content in sunflower seeds (Fig. 3). This result was supported by Criado et al. [31] who reported that AMF inoculation enhanced N concentration in grain and vegetative tissue of barley. The individual inoculation with $G$. viscosum gave higher N content in seeds compared to the control. However, the highest $\mathrm{N}$ content was observed in plants inoculated with AMF mixture (G. intraradices, G. viscosum, G. mosseae). This result is in conformity with that of Ibrahim [32] who reported that the N concentration in cotton was found to be higher in plant inoculated with the same mixture of AMF. Ramakrishnan and Selvakumar [33] showed higher N concentration in tomato seedling inoculated with AMF mixture (G. fasciculatum and G. intraradices) in comparison with single inoculation and control. Enhanced N content by AMF mixture can be explained by the suggestion that mixed AMF species which colonized roots are complementary in their uptake of nutrients from different soil pools, thus, they may be more beneficial for the plant as a mixture than any of the species separately [21, 22]. In addition, the enhanced nutrient uptake by the AMF mixture could be a consequence of greater aggregate stabilization, suggesting that a community of AMF was more efficient than single isolate [36].

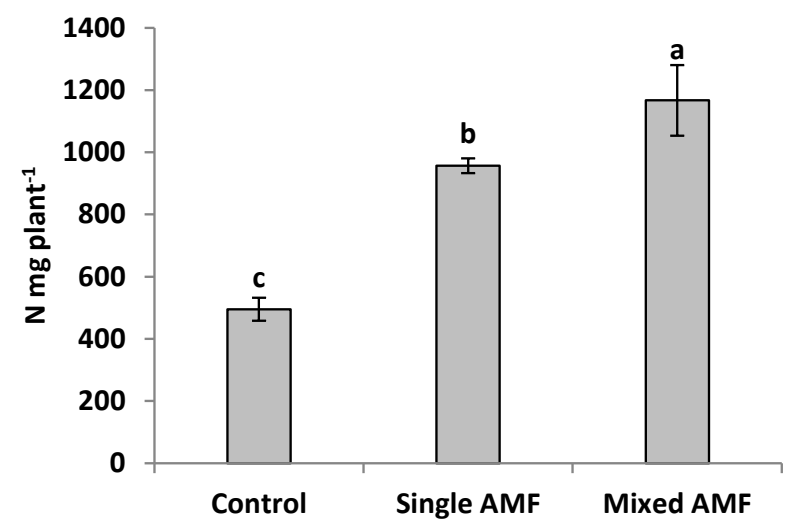

Fig. (3). Effect of the inoculation with single AMF (Glomus viscosum) and mixture of AMF on N content in sunflower seeds. Vertical bars represent means \pm SD $(n=4)$. Different letters on square bars indicate significant difference $\mathrm{P}<0.05$ lead by Fisher's Least Significant Difference (LSD) test. LSD=140. 
The inoculation with single and mixed species of AMF gave higher protein concentration in seeds compared to control (Table 1). Single and mixture inoculation significantly increased protein concentration by 19.7 and $23.4 \%$ over the control (Fig. 4). Differences between seed protein concentrations were small but were significant for the two treatments of AMF inoculation (Table 1). The maximum protein concentration was found in the treatment of mixture AMF followed by individual inoculation and minimum protein concentration was recorded in the treatment of control (Table 1). This result of sunflower seed protein increase is in accordance with the results obtained by Kumar et al. [37] who showed increased protein content in grains of AM wheat. Sarah and Burni [38] reported that AMF had shown promising effects on crude protein in mycorrhizal sorghum. However, AMF species could influence protein content differently. Silva et al. [39] found that crude protein levels in seeds were not significantly affected by inoculation of sunflower with Glomus fasciculatum. On contrary, protein content was enhanced in seeds of soya inoculated with Glomus mosseae [40], maize inoculated with AMF mixture (Glomus intraradices, Glomus aggregatum, Glomus viscosum, Glomus etunicatum, and Glomus claroideum) [41], and wheat inoculated with G. intraradices and G. mosseae [30]. The results of sunflower seed protein increase are supported by new evidence on enhanced nitrogen nutrition in AM plants [8] and the nitrogen distribution in seeds [13]. The enhanced $\mathrm{N}$ acquisition increases the amino acids synthesis in the leaves, and this stimulates the accumulation of protein in the seed [42]. Moreover, protein contents are highly correlated with P nutrition, generally ameliorated in AM plants [43], but even more improved when different AMF are involved [44].

$\square$ Single AMF $\square$ Mixed AMF

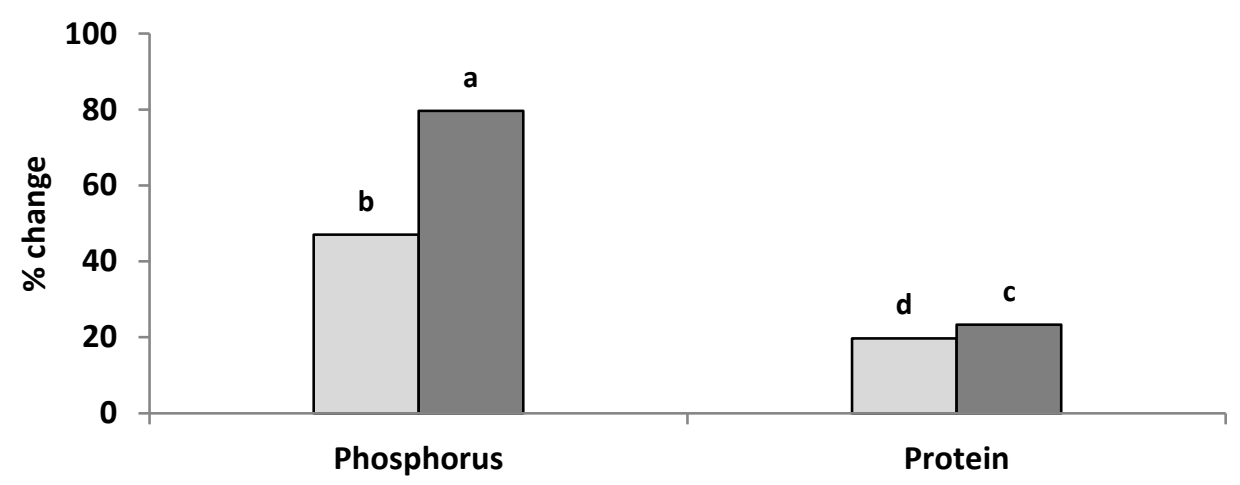

Fig. (4). Effect of the inoculation with mixed AMF and single AMF (G. viscosum) on change in protein and $\mathrm{P}$ concentration in sunflower seeds. Different letters on square bars indicate significant difference at $\mathrm{P}<0.05$. \% concentration change $=(\mathrm{AMF}-$ nonAMF) x100/nonAMF.

The enhanced accumulation of nutritious components in AM sunflower seeds was a reflection of the improved plant growth. Higher plant height and dry weight were observed in AMF inoculation in comparison with control (Table 1). The positive effect of AMF on growth and biomass was reported in sunflower [10,11]. The highest plant height and weight observed in the AMF mixture inoculation could be due to the enhancement of nutrients uptake $[45,46]$ by the different species of AMF which can have different amounts of extraradical mycelium and different efficiencies in nutrients uptake from the soil [47].

\section{CONCLUSION}

The undertaken study shows the importance of indigenous AMF as a biofertilizer for improving seed quality of confection-type sunflower crop grown under semiarid conditions. Indigenous AMF were successful in colonizing sunflower roots and resulted in better plant growth compared to non-AMF treatment. The results indicate that the mixture of indigenous AMF ( $G$. viscosum, G. intraradices and G. mosseae) gives higher values of N, P and protein content in sunflower seeds compared to the single species (G. viscosum). Therefore, the higher efficiency of AMF mixture than single species, suggests the preference of inoculation with mixed AMF inocula for the production of 'nutrient-rich high-quality seeds' of sunflower in sustainable comportment under semiarid conditions.

\section{CONSENT FOR PUBLICATION}

Not applicable. 


\section{CONFLICT OF INTEREST}

The authors declare no conflict of interest, financial or otherwise.

\section{ACKNOWLEDGEMENTS}

The author Acknowledges the Atomic Energy Commission of Syria for encouragement and technical support.

\section{REFERENCES}

[1] Lawson A. Meeting quality specifications for confectionary sunflower. Manitoba Agriculture, Food and Rural. 2006. http:// www.umanitoba.ca/ faculties/ afs/ MAC_proceedings/ 2006/ proceedings.html

[2] Guo S, Ge Y, Na Jom K. A review of phytochemistry, metabolite changes, and medicinal uses of the common sunflower seed and sprouts (Helianthus annuus L.). Chem Cent J 2017; 11(1): 95-104. [http://dx.doi.org/10.1186/s13065-017-0328-7] [PMID: 29086881]

[3] Youle RJ, Huang AHC. Albumin storage proteins in the protein bodies of castor bean. Plant Physiol 1978; 61(1): 13-6. [http://dx.doi.org/10.1104/pp.61.1.13] [PMID: 16660226]

[4] Nel AA, Loubser HL, Hammes PS. The effect of environment and cultivar on sunflower seed. II. Composition and processing quality. S Afr J Plant Soil 2000; 17(3): 138-42. [http://dx.doi.org/10.1080/02571862.2000.10634885]

[5] Tahir M, Shehzadi M. Response of spring and autumn sunflower to chemical and bio-fertilizers for yield and quality traits. Pak J Agric Res 2017; 30(2): 122-8.

[http://dx.doi.org/10.17582/journal.pjar/2017/30.2.122.128]

[6] Bhardwaj D, Ansari MW, Sahoo RK, Tuteja N. Biofertilizers function as key player in sustainable agriculture by improving soil fertility, plant tolerance and crop productivity. Microb Cell Fact 2014; 13: 66-75. [http://dx.doi.org/10.1186/1475-2859-13-66] [PMID: 24885352]

[7] Bücking H, Kafle A. Role of arbuscular mycorrhizal fungi in the nitrogen uptake of plants: Current Knowledge and Research Gaps. Agronomy (Basel) 2015; 5: 587-612. [http://dx.doi.org/10.3390/agronomy5040587]

[8] Smith SE, Read DJ. Mycorrhizal symbiosis. 3rd ed. London, UK: Academic Press Ltd. 2008.

[9] Soleimanzadeh H. Effect of VA Mycorrhiza on growth and yield of sunflower (Helianthus annuus L.) at different phosphorus levels. World Acad Sci Eng Technol 2010; 71: 414-7.

[10] Jalaluddin M, Hamid M. Effect of adding inorganic organic and microbial fertilizers on seed germination and seedling growth of sunflower. Pak J Bot 2011; 43: 2807-9.

[11] Kavitha T, Nelson R. Effect of Arbuscular Mycorrhizal Fungi (AMF) on growth and yield of sunflower (Helianthus annuus L.). J Exp Biol Agric Sci 2014; 2: 226-32.

[12] Smith SE, Smith FA, Jakobsen I. Mycorrhizal fungi can dominate phosphate supply to plants irrespective of growth responses. Plant Physiol 2003; 133(1): 16-20. [DOI: 10.1104/pp.103.024380]. [http://dx.doi.org/10.1104/pp.103.024380] [PMID: 12970469]

[13] Zhang X, Wang L, Ma F, Yang J, Su M. Effects of arbuscular mycorrhizal fungi inoculation on carbon and nitrogen distribution and grain yield and nutritional quality in rice (Oryza sativa L.). J Sci Food Agric 2017; 97(9): 2919-25. [DOI:10.1002/jsfa.8129]. [http://dx.doi.org/10.1002/jsfa.8129] [PMID: 27935053]

[14] Calvente R, Cano C, Ferrol N, Azcón-Aguilar C, Barea JM. Analysing natural diversity of arbuscular mycorrhizal fungi in olive tree (Olea europaea L.). Plantations and assessment of the effectiveness of native fungal isolates as inoculants for commercial cultivars of olive plantlets. Appl Soil Ecol 2004; 26: 11-9.

[http://dx.doi.org/10.1016/j.apsoil.2003.10.009]

[15] Mensah JA, Koch AM, Antunes PM, Kiers ET, Hart M, Bücking H. High functional diversity within species of arbuscular mycorrhizal fungi is associated with differences in phosphate and nitrogen uptake and fungal phosphate metabolism. Mycorrhiza 2015; 25(7): 533-46. [http://dx.doi.org/10.1007/s00572-015-0631-x] [PMID: 25708401]

[16] Johnson D, Vandenkoornhuyse PJ, Leake JR, et al. Plant communities affect arbuscular mycorrhizal fungal diversity and community composition in grassland microcosms. New Phytol 2004; 161: 503-15. [http://dx.doi.org/10.1046/j.1469-8137.2003.00938.x]

[17] Jakobsen I, Abbott LK, Robson AD. External hyphae of vesicular-arbuscular mycorrhizal fungi associated with Trifolium subterraneum L. 1: Spread of hyphae and phosphorus inflow into roots. New Phytol 1992; 120: 371-80. [http://dx.doi.org/10.1111/j.1469-8137.1992.tb01077.x]

[18] Munkvold L, Kjøller R, Vestberg M, Rosendahl S, Jakobsen I. High functional diversity within species of arbuscular mycorrhizal fungi. New Phytol 2004; 164: 357-64. [http://dx.doi.org/10.1111/j.1469-8137.2004.01169.x] 
[19] Jansa J, Mozafar A, Frossard E. Phosphorus acquisition strategies within arbuscular mycorrhizal fungal community of a single field site. Plant Soil 2005; 276: 163-76 [http://dx.doi.org/10.1007/s11104-005-4274-0]

[20] Zhang Q, Tang J, Chen X. Plant mortality varies with arbuscular mycorrhizal fungal species identities in a self-thinning population. Biol Lett $2011 ; 7(3): 472-4$ [http://dx.doi.org/10.1098/rsbl.2010.1040] [PMID: 21147829]

[21] Koide RT. Functional complementarity in the arbuscular mycorrhizal symbiosis. New Phytol 2000; 147: $233-5$. [http://dx.doi.org/10.1046/j.1469-8137.2000.00710.x]

[22] Gustafson DJ, Casper BB. Differential host plant performance as a function of soil arbuscular mycorrhizal fungal communities: Experimentally manipulating co-occurring Glomus species. Plant Ecol 2006; 183: 257-63. [http://dx.doi.org/10.1007/s11258-005-9037-8]

[23] Ibrahim M. Influence of Arbuscular Mycorrhizal Fungi (AMF) on the nutrition of the cotton (Gossypium hirsutum L) and its tolerance to water stress. Belgium: PhD, Gembloux Agro-BioTech 2010; p. 160.

[24] Hewitt EJ. Sand and water culture methods used in the study of plant nutrition. Tech. Comm. 22 ( $2^{\text {nd }}$ revised). Commonwealth Agricultural Bureau, London, England 1966; pp. 430-434

[25] Sieverding E. Vesicular-arbuscular mycorrhiza management in tropical agrosystems Technical cooperation. Germany: Eschborn 1991 ; p. 371.

[26] Nagornyy VD. Soil and plant laboratory analysis. Moscow: Russia Peoples' Friendship University of Russia 2013 ; p. 141.

[27] Giovannetti M, Mosse B. An evaluation of techniques for measuring vesicular-arbuscular mycorrhizal infection in roots. New Phytol 1980; 84: 489-99. [http://dx.doi.org/10.1111/j.1469-8137.1980.tb04556.x]

[28] SAS institute Inc. SAS user's guide: statistics version 912. Cary, NC: SAS Institute Inc 2004.

[29] Heidari M, Karami V. Effects of different mycorrhiza species on grain yield, nutrient uptake and oil content of sunflower under water stress. J Saudi Soc Agric Sci 2014; 13: 9-13.

[http://dx.doi.org/10.1016/j.jssas.2012.12.002]

[30] Colla G, Rouphael Y, Bonini P, Cardarelli M. Coating seeds with endophytic fungi enhances growth, nutrient uptake, yield and grain quality of winter wheat. Int J Plant Prod 2015; 9(2): 171-90. [http://ijpp.gau.ac.ir/article_2042_c68c7bdcaf6b36b4b7eb9128aeb53d33.pdf].

[31] Criado MV, H Gutierrez Boem F, Roberts IN, Caputo C. Post-anthesis N and P dynamics and its impact on grain yield and quality in mycorrhizal barley plants. Mycorrhiza 2015; 25(3): 229-35. [http://dx.doi.org/10.1007/s00572-014-0604-5] [PMID: 25242016]

[32] Ibrahim M. Arbuscular mycorrhizal isolate and phosphogypsum effects on growth and nutrients acquisition of cotton (Gossypium hirsutum L.). Adv Hortic Sci 2016; 30(3): 121-8. [http://dx.doi.org/10.13128/ahs-20247].

[33] Ramakrishnan K, Selvakumar G. Influence of AM fungi on plant growth and nutrient content of tomato (Lycopersicum esculentum Mill). International Journal of Research in Botany 2012; 2: 24-6. [https://www.urpjournals.com/tocjnls/30_12v2i4_3.pdf].

[34] Jansa J, Smith FA, Smith SE. Are there benefits of simultaneous root colonization by different arbuscular mycorrhizal fungi? New Phytol 2008; 177(3): 779-89. [http://dx.doi.org/10.1111/j.1469-8137.2007.02294.x] [PMID: 18042204]

[35] Jansa J, Mozafar A, Frossard E. Long-distance transport of P and Zn through the hyphae of an arbuscular mycorrhizal fungus in symbiosis with maize. Agronomie 2003; 23: 481-8. [http://dx.doi.org/10.1051/agro:2003013]. [http://dx.doi.org/10.1051/agro:2003013]

[36] Schreiner RP, Bethlenfalvay GJ. Plant and soil response to single and mixed species of arbuscular mycorrhizal fungi under fungicide stress. Appl Soil Ecol 1997; 7: 93-102.

[http://dx.doi.org/10.1016/S0929-1393(96)00141-2]

[37] Kumar A, Sharma KD, Gera R. Arbuscular mycorrhizae (Glomus mosseae) symbiosis for increasing the yield and quality of wheat (Triticum aestivum). Indian J Agric Sci 2011; 81: 478-80.

[38] Sarah S, Burni T. Symbiotic response of three tropical sorghum varieties to arbuscular-mycorrhizal fungal inoculation in marginal soil. Int J Agric Innov Res 2013; 1(4): 2319-1473.

[39] Silva AJN, Silva RA, Santos JS, Medeiros JCS, Carvalho FG, et al. Soil chemical properties and growth of sunflower (Helianthus annuus L.) as affected by the application of organic fertilizers and inoculation with arbuscular mycorrhizal fungi. Rev Bras Ciênc Solo 2015; 39(1): 151-61. [http://dx.doi.org/10.1590/01000683rbcs20150194]

[40] Khaitov B. Effect of synergetic interactions of arbuscular mycorrhiza fungi and rhizobia on soybean yield under saline condition. Genet Plant Physiol 2016; 6(3-4): 176-85.

[41] Berta G, Copetta A, Gamalero E, et al. Maize development and grain quality are differentially affected by mycorrhizal fungi and a growthpromoting pseudomonad in the field. Mycorrhiza 2014; 24(3): 161-70. [http://dx.doi.org/10.1007/s00572-013-0523-x] [PMID: 23995918] 
[42] Izsáki Z, Iványi I. Effect of nutrient supply on the quality of linseed and hempseed. J Nat Fibers 2005; 1: 59-75. [http://dx.doi.org/10.1300/J395v01n04_04]

[43] Smith SE, Smith FA. Roles of arbuscular mycorrhizas in plant nutrition and growth: new paradigms from cellular to ecosystem scales. Annu Rev Plant Biol 2011; 62: 227-50. [DOI: 10.1146/annurev-arplant-042110-103846].

[http://dx.doi.org/10.1146/annurev-arplant-042110-103846] [PMID: 21391813]

[44] Tian H, Drijber RA, Zhang JL, Li XL. Impact of long-term nitrogen fertilization and rotation with soybean on the diversity and phosphorus metabolism of indigenous arbuscular mycorrhizal fungi within the roots of maize (Zea mays L.). Agric Ecosyst Environ 2013; 164 : 53-61. [http://dx.doi.org/10.1016/j.agee.2012.09.007]

[45] Motosugi H, Yamamoto Y, Naruo T, Kitabayashi H, Ishii T. Comparison of the growth and leaf mineral concentrations between three grapevine rootstocks and their corresponding tetraploids inoculated with an arbuscular mycorrhizal fungus Gigaspora margarita. Vitis 2002; 41: $21-5$.

[46] Jia Y, Gray VM, Straker CJ. The influence of Rhizobium and arbuscular mycorrhizal fungi on nitrogen and phosphorus accumulation by Vicia faba. Ann Bot 2004; 94(2): 251-8.

[http://dx.doi.org/10.1093/aob/mch135] [PMID: 15205177]

[47] Oliveira RS, Castro PML, Dodd JC, Vosatka M. Different native arbuscular mycorrhizal fungi influence the coexistence of two plant species in a highly alkaline anthropogenic sediment. Plant Soil 2006; 287: 209-21.

[http://dx.doi.org/10.1007/s11104-006-9067-6]

(C) 2018 Mazen Ibrahim.

This is an open access article distributed under the terms of the Creative Commons Attribution 4.0 International Public License (CC-BY 4.0), a copy of which is available at: (https://creativecommons.org/licenses/by/4.0/legalcode). This license permits unrestricted use, distribution, and reproduction in any medium, provided the original author and source are credited. 